\title{
The aging of families with members with intellectual disabilities
}

\author{
O envelhecimento de familias com integrantes com deficiência intelectual \\ El envejecimiento en las familias con integrantes con discapacidad intelectual
}

Renata Balieiro Takebayashi' ORCID: 0000-0002-5228-5138

Hugo Fernandes'

ORCID: 0000-0003-2380-2914

Maria Goreti da Silva da Cruz' ORCID: 0000-0002-5993-9077

Marcelo Geovane Perseguino' ORCID: 0000-0002-1100-4934

\section{Selma Eloy Machado Marques'} ORCID: 0000-0003-3338-746X

Ana Lúcia de Moraes Horta'

ORCID: 0000-0001-5643-3321

'Universidade Federal de São Paulo. São Paulo, São Paulo, Brazil.

How to cite this article:

Takebayashi RB, Fernandes H, Cruz MGS, Perseguino MG, Marques SEM, Horta ALM. The aging of families with members with intellectual disabilities. Rev Bras Enferm. 2019;72(Suppl 2):184-90. doi: http://dx.doi.org/10.1590/0034-7167-2018-0535

\section{Corresponding Author:}

Hugo Fernandes

E-mail: hugoenf@yahoo.com.br

Submission: 06-26-2018

Approval: 10-07-2018

\section{ABSTRACT}

Objective: to understand the structure and dynamics of families in the late stage of the life cycle that have a member with intellectual disability. Method: qualitative research using the Calgary Family Assessment Model as methodological framework. The study had 38 participants, distributed into 10 families that had a member with intellectual disability and whose parents were elderly. The interviews were analyzed with content analysis technique. Results: the following analytical categories were evidenced: "living with intellectual disability", "communication as a strategy for encounter", "family isolation and the need for support" and "concerns about care in the future". Conclusion: families in the late life cycle who had a member with intellectual disability are arranged in a structure that overloads a single caregiver (mother), has little support network, uses communication as an instrument for understanding themselves and the other, besides having difficulties in projecting the future.

Descriptors: Nursing; Family Nursing; Intellectual Disability; Aging; Aged.

\section{RESUMO}

Objetivo: conhecer a estrutura e a dinâmica de famílias no estágio tardio do ciclo vital que possuam um integrante com deficiência intelectual (PCDI). Método: pesquisa qualitativa com uso do Modelo Calgary de Avaliação Familiar (MCAF) como referencial metodológico. Participaram 38 sujeitos, distribuídos em dez famílias que possuíam um integrante com deficiência intelectual e cujos pais eram idosos. As entrevistas foram analisadas com a técnica de análise de conteúdo. Resultados: evidenciaramse as seguintes categorias analíticas: "convivendo com a deficiência intelectual", "comunicação como estratégia de encontro", "isolamento familiar e a necessidade de apoio" e "preocupações com o cuidado no futuro". Considerações finais: as famílias no ciclo tardio da vida que possuíam um integrante com deficiência intelectual se estruturavam de modo a sobrecarregar uma única cuidadora (mãe), possuíam pouca rede de apoio, usavam a comunicação como um instrumento de compreensão de si e do outro, além de terem dificuldades de projeção para o futuro.

Descritores: Enfermagem; Enfermagem de Família; Deficiência Intelectual; Envelhecimento; Idoso.

\section{RESUMEN}

Objetivo: conocer la estructura y la dinámica de familias en la etapa tardía del ciclo vital que tienen un integrante con discapacidad intelectual. Método: investigación cualitativa que utiliza el Modelo Calgary de Evaluación Familiar (MCEF) como referencial metodológico. Participaron 38 individuos, distribuidos en 10 familias que tienen un integrante con discapacidad intelectual y cuyos padres eran adultos mayores. Se analizaron las entrevistas mediante la técnica de análisis de contenido. Resultados: se destacaron las siguientes categorías analíticas: "Conviviendo con la discapacidad intelectual", "Comunicación como estrategia de encuentro", "Aislamiento familiar y la necesidad de apoyo" $y$ "Preocupaciones con el cuidado en el futuro". Consideraciones finales: las familias en el ciclo tardío de vida que tienen un integrante con discapacidad intelectual se estructuran con una sobrecarga a una sola cuidadora (la madre), cuentan con poca red de apoyo, utilizan la comunicación como un instrumento de entendimiento de sí misma y del otro, además de enfrentarse a dificultades para hacer planes para el futuro.

Descriptores: Enfermería; Enfermería de la Familia; Discapacidad Intelectual; Envejecimiento; Anciano. 
The aging of families with members with intellectual disabilities Takebayashi RB, Fernandes H, Cruz MGS, Perseguino MG, Marques SEM, Horta ALM.

\section{INTRODUCTION}

Persons with disabilities (PwD) are those who have physical, intellectual or sensory impediments that may obstruct their full and effective participation in society ${ }^{(1)}$. In other words, disability can be understood as a physical, intellectual or sensorial limitation that is permanent or transitory and impairs a person's ability to perform his or her basic activities of daily living (BADL) ${ }^{(2)}$.

The classification of intellectual disability, which was once based only on intelligence quotient, now takes into account cognitive functioning, adaptive behavior and developmental period, and can be characterized by significant limitations in one of these dimensions before the 18 years of age $\mathrm{e}^{(1)}$.

Several families face the reality of intellectual disability in one of their members, leading to demands for specific care according to the individual's autonomy and functioning degree ${ }^{(3)}$.

However, a new reality emerges in recent decades: the increase in longevity in Brazil and in other developing countries, due to the advancement of biomedical technologies, better health conditions and reduction of mortality due to communicable diseases. Thus, people with intellectual disabilities (Pwld) also started having high life expectancy, requiring care in adulthood or even in old age $\mathrm{e}^{(4)}$. In addition, their parents, caregivers and family members also age up and enter the late phase of the life cycle (old age) where they also sometimes require help in BADL. Those who have always taken care of others may face limitations in maintaining their own and others' care.

The support for BADL throughout life is common in families with a Pwld. With aging, these people may need broader support, and their family nucleus, also getting older, tends to lack care, which may increase the vulnerability of this family ${ }^{(5)}$.

As indicated by an integrative review on nurses' performance toward people with disabilities, there is still a shortage of studies on the theme involving families ${ }^{(6)}$. Therefore, this study is justified by the recognition of the existing gap in the literature and by the understanding that the nurse must know the dynamics and structures of families that experience this reality in order to plan and execute care centered on the family, not only on one of its members.

In this context, the following question arose: how are the structures and dynamics of families during the late stage of the life cycle when having a member with intellectual disability?

\section{OBJECTIVE}

To understand the structure and dynamics of families in the late stage of the life cycle that have a member with intellectual disability.

\section{METHOD}

\section{Ethical aspects}

The study was held according to national and international ethics standards for research with human subjects and was approved by the Research Ethics Committee of the Universidade Federal de São Paulo and by the Municipal Health Secretariat of São Paulo, under processes no. 1,135,497/2015 and 1,159,893/2015.

\section{Type of study}

This is an exploratory and descriptive research, of qualitative approach. The Calgary Family Assessment Model (CFAM) was used as methodological framework.

CFAM has been a methodological resource for family assessment in a multidimensional way. Created in Canada in the 1990s, and currently used by nursing schools in several countries, its organization includes three dimensions of family assessment. The first is the structural dimension, which includes research on who is part of this system and what is its context (such as social class, religion, ethnicity, among others). The second is called the developmental dimension, because it focuses on considerations about the stage of the life cycle in which the family finds itself, the tasks of members, and the existing bonds. Finally, the third dimension is the functional one and seeks to investigate instrumental aspects, such as activities of daily living, and expressive aspects, such as the forms of communication adopted, the way of solving existing problems, roles, influences, beliefs and the existing alliances ${ }^{(7-8)}$.

\section{Eligibility criteria}

Inclusion criteria were families in the late life cycle that had at least one member with intellectual disability aged 35 or over, attended by the Strategy of Health Follow-up for the Person with Disability (APD - Estratégia de Acompanhante de Saúde da Pessoa com Deficiência), of the Municipal Health Secretariat of São Paulo at least 1 year ago. APD is a specialized service existing in the city of São Paulo since 2010. It is inserted in the Network of Care for Persons with Disabilities (Rede de Cuidado à Pessoa com Deficiência), whose main objective is to provide support to people with disabilities so that they can achieve in the territory and localities resources for their care, stimulating the protagonism and independence of those served. Its target population are Pwld, who need support for taking care of their health. The team that makes up this strategy should consist of one nurse coordinator, one occupational therapist, one psychologist, one speech therapist and at least six accompanying adults for Health of the Person with Disability. Each team provides follow-up for at least $80 \mathrm{Pwld}^{(9)}$.

Exclusion criteria were families whose caregivers were younger than 60 years and those with persons with psychiatric or neurological disorders, which made data collection impossible. Eligible families were presented to the first researcher by APD managers, which facilitated the creation of bond and allowed the scientist to explain the objectives and justification of the study with clarity to the subjects. The team of researchers who participated in the process of construction and analysis of material consisted of nurses and a pedagogue. APD managers did not participate as researchers.

\section{Data collection and organization}

Ten families participated in the study, totaling 38 subjects interviewed, presented with the denominations of kinship and family identification number (example: Father 1, Mother 1, Son 1 etc.). Narratives of people with intellectual disabilities were identified with the acronym Pwld, and the number assigned to the family was at the end (example: Pwld 1). The interviews were carried out according to the availability of the families and their home. They 
The aging of families with members with intellectual disabilities Takebayashi RB, Fernandes H, Cruz MGS, Perseguino MG, Marques SEM, Horta ALM.

were divided into three moments, prioritizing the dimensions of the CFAM, namely: first moment: it was sought to understand the structural and developmental dimensions of the families; second moment: the aspects related to the instrumental and expressive functionality of the families were evaluated; and third moment: the data collected were returned to the subjects for validation.

The collection was held in families' households, after scheduling. It was carried out by the first researcher, who is a nurse, specialist in mental health and family therapy, besides having experience and qualification in qualitative research. The semi-structured interview resource was used as a guiding question: "how has it been for you to experience the intellectual deficiency of one of your members?". Narratives were recorded in Mp4 electronic device, lasted 90 minutes on average and were later transcribed. The collection period was from March to October 2016.

\section{Data analysis}

To analyze the interviews, steps for content analysis, developed by Bardin, which were pre-analysis, material exploration and treatment of results were held ${ }^{(10)}$. In pre-analysis, the authors skimmed the transcribed material of the interviews made with the families and searched the elements that could compose the corpus of the analysis. In the exploration of the material, that aim was to define the categories by classifying the constituent elements into analog groups by frequency of the recording units. Finally, the data were inferred and interpreted.

\section{RESULTS}

Most of the families interviewed (80\%) presented as type of formation the nuclear heterosexual family and had more than one child. Almost all families (90\%) belatedly discovered that one of their members (children, in all cases) had intellectual disability (after 3 years of life). A large part (60\%) integrated or had ties with evangelical religious institutions and participated in activities focused on spirituality. All families had income of up to three minimum wages and only three Pwld received welfare benefits for the elderly and the disabled person (BPC) of the Brazilian Social Security Institute (INSS - Instituto Nacional de Seguridade Social). The Pwld were aged between 35 and 46 years, and the responsible ones had a mean age of 65 years.

The results showed that families have particular forms of structure, development and functionality after the discovery that one of their members has intellectual disability. Four thematic categories emerged after analyzing the narratives: "living with intellectual disability","communication as a strategy for encounter","family isolation and the need for support" and "concerns about care in the future".

The thematic category "Living with intellectual disability" presented aspects related to diagnosis, activities of daily living (basic and instrumental), caregivers' role, potential and need of support for Pwld, interpersonal relationships, worries and longings.

Prior to diagnosis, families believed that behavioral difference and learning difficulty consisted of a personality issue, not of a symptom of the disability.

When she [Pwld 10] was discharged, the health center provided no diagnosis and that was it. Then, because she was a very nervous person, she took a while for walking, for talking, so for us it was normal (Older sister 10)

Of the little I remember, my mother always told the doctors that he had an uneven gait, right?! That he had no knowledge of money, of place, of taking public transportation alone, doing these things alone, we knew he didn't. But the point is that no one ever researched the causes, we just set it aside and aside... (Youngest sister 10)

Another belief that emerged in this category was about the cause of the disability, in which family guilt became evident, for reasons of denial of gestation, or blaming on the family of paternal or maternal origin due to other similar cases.

Then I took her to the Association of Parents and Friends of the Exceptional ones [APAE - Associação de Pais e Amigos dos Excepcionais], they did the exams and the result was that she had intellectual disability... they told me that it was because I rejected her and she was born with intellectual disability... And deep inside I feel guilty. Why have I rejected her in the past, huh?! (Mother 5)

Prejudice appeared as family difficulty and in social interaction, presenting data with pejorative statements and indicating that intellectual disability was a problem for families.

It'sjust that it's very difficult, you know?! Ah... I think all the people who havesuch aperson in the family know how difficult it is within their own family to accept it. Look, I have nine siblings, he has six. Ours... All that we have heard and everything, right, honey?! You know?! (Mother 3)

Yes, not lately because he has captivated most of them with his way of being and today he is very dear, but there was a period that he was kind of rejected by the family. We heard: the video recorded by the family was so beautiful, it's a pity that this retarded ruined it. (Father 3)

The family adaptation to intellectual disability and rearrangements of the system were perceived through instrumental and expressive functional evaluation during BADL, observing the roles, alliances and unions, and the influences and power within family dynamics. Parents' participation in imposing limits to the Pwld with reports about using daily repetitions to fix these limits, always valuing the family hierarchy. In addition, it was evidenced that the care was alternated between the father and the mother, although the predominance was maternal. It is also worth noting that Pwld need others to do the BADL for them.

Does the Pwld 8 obey the mother more? (Researcher)

She does! Because I say: there is more to this than meets the eye, you cannot say this, you cannot do that, you have to respect your father, because you only have one father, you only have one mother... I explain everything, every single little thing... the same litany every day! (Mother 8)

Is your mother that takes care of you? (Researcher)

Yes, she does everything. (Pwld 5)

I only don't bathe her. At first I bathed her, after the lady came here she said to stop it. No, ma'am, she has to allow it. For example, when she is menstruating, I have to put the sanitary pad for her. (Mother 5) 
The aging of families with members with intellectual disabilities Takebayashi RB, Fernandes H, Cruz MGS, Perseguino MG, Marques SEM, Horta ALM.

Is just that I don't even I say anything, right?! Her mother is not going to be there with her and her brother forever. So, you have to stimulate her to do a little bit, to make her little intimate things too. (Sister-in-law 5)

Several family members requested the Pwld's assistance in the domestic tasks, being possible to verify their potentials, even in situations that demanded care with the drug therapy.

In addition, they gradually perceived the Pwld's potentials, valued their autonomy and independence and verified their behavioral improvement over the years.

\author{
He does a lot. (Mother 1) \\ This coarse service... she does it. (Mother 8)
}

Yeah, I do the same thing she said there, my pace... I clean the yard, I... I, right?! I pick up the laundry basket for my mother to hand on the clothesline, she can't pick up the basin because of the stairs there, she has a knee problem, so I pick it up. (Pwld 8)

The thematic category "Communication as a strategy for encounter" emerges from narratives in the aspects of emotional and circular communication, of influence and power, besides the search for solving problems and understanding oneself and the other. The main communication difficulty was expressed by the Pwld's agitated behavior. On the other hand, the facilitators of communication are expressed by perceiving the other as nonverbal communication and by the understanding of what was said in verbal communication, even if it was not clear to others.

Then, if he gets nervous, how do you deal with the situation? (Researcher)

I try to play with him because sometimes he sets upon us... right?! Then, sometimes I tell the aunt: I'd better leave because he thinks that everyone is in his space. (Cousin 4)

And then it takes 5 minutes, 20 tops! And then that is it. It's no use because things get bad, right, son?! (Mother 3 )

And there is the mood, which varies a lot, right?! At the same time that he is in a good mood and all, suddenly he changes... I've lost count of how many times I've been embarrassed on the street, because he spent 5 minutes in anything, and then... the more you say, the worse! (Father 3)

But does he speak out loud? (Researcher)

He does! He keeps doing this... you know? [demonstrates gestures]. (Mother 3)

He gets aggressive. He gets aggressive, but he doesn't beat us. This he doesn't. (Father 3)

The forms of verbal and nonverbal communication appeared as necessary tools for understanding the context and the relationships that implied in the comprehension of the emotions and attitudes demonstrated.

When she's happy she sings alone, she talks to herself. (Sister 9)

\section{When is the middle Pwld 9 happy or content? (Researcher)}

He dances, he sings... there, over there... he does this [whirling around]. (Sister 9)

When he's upset, he goes to sleep, or he gets disturbed... nervous and keeps talking, I don't know what [babbling]... (Older Pwld 9)

I get nervous and can't sleep... (Middle Pwld 9)

He talks and talks and gets angry. (Older Pwld 9)

In the category "Family isolation and the need for support", the family emphasized the importance of identifying the external structure, expanding the support network to share the care and facilitate access to various care resources. The families commented that the isolation arose due to the architectural barriers and the Pwld' locomotion difficulty. This difficulty was increased for the whole family with the aging of members, especially of the main caregivers. The need for external support was a common feature. The family seeks alternatives with their extended family and wider systems. Sometimes members of the extended family lived nearby but provided no assistance; on the other hand, the distant family was willing to collaborate, however, only in very essential situations. Thus, the family experiences solitude, overload and difficulty of support in the daily life.

It's just that I don't drive. I've never driven nor have l ever gotten a driver's license or anything like that. The neighborhood that we live has nothing! There's nothing here! She's goes to work all day, I stay here with him... the bus doesn't... doesn't... You cannot get on the bus. (Father 3 )

I already fell with him on the bus. Drivers have no patience. (Mother 3)

And who helps you? (Researcher)

Nobody. It's just the three of us, right, son?! (Mother 3)

His brother comes by, stays with him a little and all, but he doesn't get involved. (Father 3)

Look, here there were some brothers from the church who came by, they like, they started to come to visit, but they don't come anymore, they were getting used to come here at home, then they'd pray, they'd stay there in the middle, clap their hands, but then they walked away as well. (Father 1)

And when one needs to go out with Pwld 1, who goes? (Researcher)

Oh, it's hard to go out, he isn't going out, no. (Mother 1)

Her brother stayed in the hospital for four months, died now... He has his children. And who do I have? What if I end up in the hospital? Who's going to visit me there? No one! All this I think, right? Let's suppose I'll take the treatment, of course she [wife] will care about me, but how is she going there to the hospital? (Father 1)

In the category "Concerns about care in the future", families highlighted the hope for improvement, linked to divine help; on the other hand, they perceived their limitations due to aging. The 
future was, often, not perceptible. Some denied the impossibility of taking care of the Pwld referring to being attentive only to the present moment. Others portrayed aging and proximity to death, generating the search for other resources to continue the care for Pwld. In some situations, to carry out the activities, the families perceived that, with aging, physical limitations of locomotion, joint pains and slowness to perform activities appeared in both Pwld and caregivers.

To work, I work, I'm a worker. I like to do something, I'm not handling to do a lot... (Father 1)

Why? (Researcher)

Because of age, because of the age itself, stairs... I like to tend my garden... This here has no future because I cannot do it all alone, look, everything up there is mine, lately I don't even go up there. I like to plant a garden, pickup a corn, no problem with that. Getting old, if there was someone else to help me... the way this is, it does not work. (Father 1)

The developmental evaluation (stages), together with functional evaluation (activities of daily living) and expressive evaluation (problem solving), was highlighted, leading to moments of reflection about the future, which raised concerns - about the possibility of death of the caregiver. Given these reflections, families visualized moving from their location and/or changing the structure of their dwelling.

Oh, dang! I don't even know about the future... Oh, my sister says she's gonna buy a little house for me and for her. She already said that in the future she'll take care of me. (Pwld 7)

So, one thing I ask God every day is that like, the day he'll have to take my grandmother and my grandmother, that I at least have graduated, that I at least have a stability. Because like, my mom works by day, so, in this case, she's gonna depend on me, because from that to rent the house, right?! (Sister 7)

The Pwld also reflected on their future after their caregivers' death and reported their expectation of overcoming the difficulties.

Every day we get older and worried about how he will manage without us, right? (Father 2)

I can say that I'm prepared to face everything. (Pwld 2)

Old age for me will not tie! It's beautiful the person with white hair. After my father dies, I have to face life, as people say. Go to the fight, right?! (Pwld 2)

\section{DISCUSSION}

Despite advances in the diagnostic process, the families in this research obtained it late. In addition, they reported uncertainties and beliefs about the etiology of cases, such as genetics of one parent and maternal rejection in gestation. The current literature indicates that the causes of intellectual disability are obscure between 30 and $50 \%$ of the cases ${ }^{(11)}$.

Researchers point out that $83.6 \%$ of Pwld are cared for by family members, and almost $70 \%$ of them depend on their parents for survival, even after they become adults ${ }^{(12)}$. In this study, primary care was offered more frequently by mothers, followed by the father. The siblings were their main support, helping in more complex activities, such as shopping, access to appointments and outside activities, due to the limitation of the parents' aging. Studies have reported that six to eight people are required to perform effective and safe support for Pwld, but the results of this study have indicated up to two people as elements for support ${ }^{(13)}$.

Social vulnerability can increase financial difficulties, influencing the care delivery ${ }^{(12)}$. Often, a parent or responsible person quit his or her job to take care of the Pwld. In this study, the three participating families received BPC, offered for families with per capita income less than $25 \%$ of the minimum wage. Families with a member with intellectual disability have poor quality of life when income and education levels are lower ${ }^{(14)}$.

The families of this study placed their belief in God as one of the most important forces for their support network. Attachment to spirituality increases the ability of families to cope with daily difficulties and uncertainties. However, the very vigorous deposition of faith in superior entities may lead to little family responsibility in the planning of the future ${ }^{(15)}$.

The socialization resources to which people with disabilities are exposed can stimulate or inhibit their abilities, as well as their sense of autonomy, independence and self-protection ${ }^{(16)}$. Intrafamily prejudice and moments of abuse against the Pwld, such as verbal offenses and public embarrassment were reported. These situations worried families, affecting their dynamics and generating discomforts among members. The disease itself does not constitute the stigma, but rather, the relationship that is built between its image and the normative standards of society ${ }^{(17)}$.

Access to information by the family member with intellectual disability and by the family as a whole can increase his or her sense of control, making the person able and autonomous enough to act appropriately in the different contexts of life ${ }^{(14)}$.

Pwld participating in this study had little or no stimulation in their infancy, not having fulfilled the autonomization process considered normative and remaining dependent on the families. This factor may have contributed to the fact that more than half of the Pwld did not participate in any activity when they were enrolled in the APD.

We came across with only one participant in the labor market, acting as a maid (hourly housekeeper), legitimizing the literature that states that, deliberately or not, Pwld have been deprived "of a series of cultural and intellectual assets, damaging them in their process of social and labor insertion"(18).

Physiologically, the aging process is dynamic and progressive, accompanied by morphological, functional and biochemical changes that progressively alter the organism, making it more vulnerable ${ }^{(19)}$. Given the above, the professional's focus should not rely only on the problem, but also on the relationships between people and their contexts, because, despite significant variations in how individuals grow older, each one experiences this process in a unique way. In this study, old age brought with it physical changes in the caregivers, but without making them totally dependent on third parties for BADL and for fulfilling their functions with Pwld.

The nurses, besides providing specific support for Pwld, should apply family approach to confer support for improving quality of life, being important to verify how families believe that their 
The aging of families with members with intellectual disabilities Takebayashi RB, Fernandes H, Cruz MGS, Perseguino MG, Marques SEM, Horta ALM.

needs are met or not, stimulating protagonism, seeking to know their histories and to recognize their priorities in care ${ }^{(14,17)}$.

To plan continued care for Pwld and his or her health may contain uncertainties. Participants must be able to express their inability to make future plans ${ }^{(20)}$. Family aging and the reflection about the possible absence of the caregiver or their inability to continue protecting the Pwld were concerns manifested in this study. Among the family concerns, it is worth noting the maintenance of care and protection of Pwld, as well as the legal, financial and housing situation after the loss of the primary caregiver ${ }^{(13)}$.

The primary concern for older mothers of Pwld is the inability to take care of their children as they get older; many said they wished to live at least one day longer than their disabled children, because they considered themselves the only source for protecting the Pwld ${ }^{(12)}$. The avoidance, the lack of guidance and the lack of adequate residential provision caused suffering and were obstacles to the development of future plans ${ }^{(15)}$.

To minimize this aspect, it is interesting that social investments exist to provide such subjects with conditions of development that enable them to learn about the existence and usefulness of their own voice, as well as about their rights and ways of employing them ${ }^{(16)}$.

Pwld also expressed concerns about their aging parents, raising the need of helping with domestic activities and gaining more autonomy after their death. For some, thinking about it causes anguish and denial, elucidated by behavioral changes and agitation.

Some families did not feel heard and had to deal with the limitations of future prospects alone ${ }^{(15)}$. Thus, nurses can be key parts in the care for families. It is pointed out that the process of communicating with the other is not only summarized in words. The body language is expressed in gestures, in looks and in emotions. Some Pwld are less able to verbalize feelings, but sometimes they can do so through challenging behaviors, requiring caregivers' ability and empathy to understand their needs ${ }^{(21)}$.

The expressive aspect cited by the CFAM was presented in various ways by families, such as in beliefs, in the establishment of roles, in influences and in power relations. However, there was more emphasis on communication in its various forms (emotional, verbal, nonverbal and circular). Therefore, this study suggests that interventions aimed at communication, such as qualified listening and dialogue, be adapted to meet the needs of these families in the late stage of the life cycle, reducing mental suffering, relieving anxieties about the future, seeking to avoid moments of crisis and promoting improvements in the well-being and quality of life of those involved ${ }^{(15)}$.

\section{Study limitations}

This research has as a limitation the fact that families are enrolled in a rehabilitation strategy existing only in the municipality of São Paulo, to date. Thus, families that live in other areas or lack similar services may undergo different experiences during the late stage of the life cycle.

\section{Contributions to the field of nursing}

The nurse must be open to the broad understanding of contexts, integrating practical and theoretical knowledge to recognize new meanings about aging and intellectual disability. The nurse should also value the family as the owner of a knowledge conquered with their life experience and competent to solve and live their difficulties seeking new coping strategies.

As advances for scientific knowledge, we highlight the use of the Calgary Family Assessment Model as a way to facilitate the understanding of the structure and dynamics of families in the late stage of the life cycle, or in old age. Nurses can use this instrument as a facilitating strategy for expanding the vision of the family system in the assessment and in the proposal for intervention of necessary care. Deepening the knowledge in the dynamics and experiences of the families that have a Pwld allows the creation of subsidies for interventions and nursing practices that favor greater autonomy of the subjects and harmony of the system.

\section{FINAL CONSIDERATIONS}

Families going through aging and that have an intellectually disabled person develop strategies of adaptation to the reality of the diagnosis of the loved one, often occurring late. All families have undergone changes due to the aging of both Pwld and especially of their caregivers.

Mothers were the most burdened with the care tasks, and even older women remain with this assignment, having also to face the difficulties of taking care of themselves due to the limitations of aging. In addition, the families studied presented great concern for the future due to the little existing support network, affecting its functioning and dynamics.

Communication has shown itself to be a way of sharing feelings and understanding the other, especially the Pwld, given the particularities of expressions created over the years.

Finally, other research on the subject must be carried out, and its results shared to promote inclusive, safe and focused health care not only on the person but on the whole family system.

\section{REFERENCES}

1. Fiorati RC, Elui VMC. Social determinants of health, inequality and social inclusion among people with disabilities. São Paulo (SP): Rev Latino-Am Enfermagem [Internet]. 2015 [cited 2017 Mar 14];23(2):329-36. Available from: http://www.scielo.br/pdf/rlae/v23n2/0104-1169rlae-23-02-00329.pdf

2. Dias SS, Oliveira MCSL. Intellectual disability according to the cultural-historical approach: a path to adult development. Bauru (SP): Rev Bras Educ Espec [Internet]. 2013 [cited 2017 Mar 13];19(2):169-82. Available from: http://www.scielo.br/pdf/rbee/v19n2/a03v19n2.pdf

3. Crnic KA, Neece CL, Mclntyre LL, Blacher J, Baker BL. Intellectual disability and development risk: promoting intervention to improve child 
The aging of families with members with intellectual disabilities

and family well-being. Child Dev. 2017;88(2):436-45. doi: 10.1111/cdev.12740

4. Reppermund S, Trollor JN. Successful ageing for people with an intellectual disability. Curr Opin Psychiatry. 2016;29(2):149-54. doi: 10.1097/ YCO.0000000000000228

5. Grey JM, Totsika V, Hastings RP. Physical and psychological health of family carers co-residing with an adult relative with an intellectual disability. J Appl Res Intellect Disabil. 2017;31(Suppl 2):191-202. doi: 10.1111/jar.12353

6. Alves TJL, Pires MNA, Servo MLS. A look at the role of the nurse in the care for people with disabilities: integrative review. REUOL. 2013;7(7):4892-98. doi: 10.5205/reuol.4700-39563-1-ED.0707esp201310

7. Patton R, Chappelle N, Fisher U, McDowell-Burns M, Pennington M, Smith S, et al. Teaching general systems theory concepts through open space technology: reflections from practice. J Syst Therap. 2016;35(4):1-10. doi: 10.1521/jsyt.2016.35.4.1

8. Monteiro GRSS, Moraes JCO, Costa SFG, Gomes BMR, França ISX, Oliveira RC. Application of the Calgary Family Assessment model in hospitals and in primary health care: an integrative review. Aquichan. 2016;16(4):487-500. doi: 10.5294/aqui.2016.16.4.7

9. São Paulo. Estratégia acompanhante de saúde da pessoa com deficiência - documento norteador [Internet]. São Paulo: Secretaria Municipal de Saúde; 2016 [cited 2017 Apr 28]. Available from: https://www.prefeitura.sp.gov.br/cidade/secretarias/upload/saude/APD\%20 DOCUMENTO\%20NORT EADOR\%2017112016.pdf

10. Urquiza MA, Marques DB. Content analysis in terms of Bardin applied to corporate communications under the sign of a theoretical and empirical approach. Entretextos. 2016;16(1):115-144. doi: 10.5433/1519-5392.2016v16n1p115

11. Tassé MJ, Luckasson R, Schalock RL. The relation between intellectual functioning and adaptive behavior in the diagnosis of intellectual disability. Intellect Dev Disabil. 2016;54(6):381-90. doi: 10.1352/1934-9556-54.6.381

12. Kim G, Chung S. Elderly mothers of adult children with intellectual disability: an exploration of a stress process model for caregiving satisfaction. J Appl Res Intellect Disabil. 2016;29(2):160-71. doi: 10.1111/jar.12166

13. Qualls SH. Caregiving families within the long-term services and support system for older adults. Am Psychol. 2016;71(4):283-93. doi: $10.1037 / \mathrm{a} 0040252$

14. Vilaseca R, Gràcia M, Beltran FS, Dalmau M, Alomar E, Adam-Alcocer AL, et al. Needs and supports of people with intellectual disability and their families in Cataloni. J Appl Res Intellect Disabil. 2015;30(1):33-46. doi: 10.1111/jar.12215

15. Pryce L, Tweed A, Hilton A, Priest HM. Tolerating Uncertainty: Perceptions of the future for ageing parent carers and their adult children with intellectual disabilities. J Appl Res Intellect Disabil. 2015;30(1):84-96. doi: 10.1111/jar.12221

16. Wanderer A, Pedroza RLS. Violence as cross-cutting theme in disability studies: needed interconections. Estud Pesqui Psicol [Internet]. 2015 [cited 2017 Jul 10];15(1):178-95. Available from: http://pepsic.bvsalud.org/pdf/epp/v15n1/v15n1a11.pdf

17. Vieira DK, Favoreto CAO. Narratives on health: reflections on care for people with disabilities and genetic disease within the Brazilian National Health System. Interface. 2016;20(56):89-98.doi: 10.1590/1807-57622015.0203

18. Redig AG, Glat R. Inclusion of people with intellectual disabilities in laboral activities: a work customization program. Ensaio Aval Pol Públ Educ [Internet]. 2017 [cited 2017 July 10];25(95):330 55. Available from: http://www.scielo.br/pdf/ensaio/v25n95/1809-4465ensaio-S0104-40362017002500869.pdf

19. Carneiro DN, Vilela ABA, Meira SS. Evaluation of cognitive deficit, mobility and activities of daily living among elderly. Rev APS [Internet]. 2016 [cited 2016 Jun 19];19(2):203-9. Available from: http://ojs2.ufjf.emnuvens.com.br/aps/article/view/7154/3453

20. Low LPL, Chien WT, Lam LW, Wong KKY. A qualitative study protocol of ageing carers' caregiving experiences and their planning for continuation of care for their immediate family members with intellectual disability. BMC Geriatrics. 2017;17(81):1-6. doi: 10.1186/s12877-017-0473-9

21. Collins K, Gratton C, Heneage C, Dagnan D. Employed carers' empathy towards people with intellectual disabilities: the development of a new measure and some initial theory. J Appl Res Intellect Disabil. 2015;30(1):133-46. doi: 10.1111/jar.12226 